\title{
Salmonella sp. Detection in Elementary School Street Foods in Surabaya
}

\author{
Adelia Anggasta Adzhani', Marijam Purwanta ${ }^{2 *}$, Ivan Rahmatullah ${ }^{3}$ \\ ${ }^{1}$ Faculty of Medicine, Universitas Airlangga, Surabaya, Indonesia \\ ${ }^{2}$ Department of Microbiology, Faculty of Medicine, Universitas Airlangga - Dr. Soetomo General Hospital, Surabaya, \\ Indonesia \\ ${ }^{3}$ Department of Public Health and Preventive Medicine, Faculty of Medicine Universitas Airlangga, Surabaya, Indonesia
}

\section{A R T I C L E I N F O}

\section{Article history:}

Received 31 August 2018

Received in revised form 22

September 2018

Accepted 3 October 2018

Available online 30 October 2018

\section{Keywords:}

Street food Drinks,

Salmonella sp.,

Bacterial Contamination,

Pathogen Bacteria,

Elementary School.

*) Corresponding author:

marijampurwanta@yahoo.com

\begin{abstract}
A B S T R A C T
Introduction: Street foods are food and drink which are processed on the selling spot and/or served as ready-to-consume foods by food vendors to sell to people. Foods and drinks which are rested for too long in the environment will make it possible to get contaminated by pathogen microbes and then results in disease. One of the microbes that is considerably contaminating street foods is Salmonella. We aim to identify Salmonella on drink which are offered in the canteens of Public Elementary School.

Methods: This research is design as a descriptive observational, including incubation in Selenite broth, streak in MacConkey agar, and species identification using biochemical tests.

Results: There were no Salmonella sp. in drinks sample of street foods which are offered both inside and outside the canteens of Public Elementary School 1 Surabaya, but other gram-negative bacteria contaminated foods.

Conclusion: The street foods in elementary school, both the main ingredients and tools used during food processing and serving, still have contamination from pathogen, especially gram-negative bacteria. The vendors and sellers need to be taught how to process and serve foods in better hygiene.
\end{abstract}

\section{Introduction}

Indonesia is a developing country with high incidence of infectious diseases. Infectious diseases vary including respiratory infections and digestive infections. Diarrhea is the most common digestive disease and a health problem in Indonesia. In 2000, diarrhea Incident Rate (IR) was $301 / 1000$ population, in 2003 was $374 / 1000$ population, in 2006 was $423 / 1000$ population and in 2010 was $411 / 1000$ population. In 2008 , an outbreak occurred in 69 districts with 8133 cases and 239 deaths (CFR 2.94\%). In 2009, an outbreak occurred in 24 subdistricts with 5756 cases and 100 deaths (CFR 1.74\%), whereas in 2010, outbreaks occurred in 33 sub-districts with 4204 cases and 73 deaths (CFR 1.74\%). ${ }^{1}$

Diarrhea is the top 10 most common diseases in Indonesia and main cause of malnutrition and death in children. ${ }^{2}$ Diarrhea can be classified into two: acute diarrhea when diarrhea occurs suddenly in less than 14 days and chronic diarrhea, which lasts more than 14 days. The etiology of diarrhea are infection and noninfection. Infectious diarrhea is the most common diarrhea which is caused by various organisms, such as Salmonella. Salmonella are causative agent of infection, ranging from gastroenteritis, septicemia to enteric fever. ${ }^{3}$

Salmonella bacteria live in the human intestinal tract and transmit through contaminated foods, although person to person transmission is possible. ${ }^{4}$ The contamination occurs in three ways, namely direct contamination, cross contamination and recontamination, ${ }^{5}$ and are related to food and beverage processing, materials and tools, personal hygiene, serving and storing. The food and beverages contamination are called foodborne illness. ${ }^{6}$ 
Snacks is ready-to-eat foods and beverages processed by the vendors with the purpose of sale to the public other than those served by catering services, restaurants, and hotels. Snacks is needed, moreover it is relatively affordable. Although the price is low, the community need to consider its hygiene. ${ }^{2}$ The activity of school-age children influences their snack selection. This is also influenced by the products packaging. As the street food snacks are susceptible to microbial contamination, low level of education and awareness about food hygiene and safety, as well as poor hygiene and sanitation practices, it is important to know the microbial contamination in street food snacks. ${ }^{7}$

\section{Methods}

This study was a descriptive observational using crosssectional design. The sample were street food beverages that are sold inside and outside the canteen in one of the elementary schools in Surabaya. The samples were collected by buying from the chosen vendors. All of the samples were collected in the morning and immediately examined at Department of Microbiology, Faculty of Medicine, Universitas Airlangga.

Salmonella bacteriological examination were performed by using Selenite enrichment broth and MacConkey agar. One milliliter of each samples was cultured on Selenite Enrichment Broth media and then incubated at $37^{\circ} \mathrm{C}$ for 24 hours. The multiplications were cultured on MacConkey media and re-incubated at $37^{\circ} \mathrm{C}$ for 24 hours. Furthermore, the suspected colonies were tested biochemically by planting on a media

Table 1. The Types and Locations of the Samples

\begin{tabular}{|c|c|c|}
\hline No. & Locations & Types \\
\hline \multirow[t]{5}{*}{1.} & \multirow[t]{5}{*}{ Canteen inside the school (A) } & Tea \\
\hline & & Orange drinks \\
\hline & & Chocolate milk "Milo" \\
\hline & & Ice cream "cap jempol" \\
\hline & & Ice cubes \\
\hline \multirow[t]{6}{*}{2.} & \multirow[t]{6}{*}{ Canteen inside the school (B) } & Tea \\
\hline & & Chocolate milk "Milo" \\
\hline & & Milk \\
\hline & & Syrup drinks \\
\hline & & Grass jelly drinks \\
\hline & & Ice cubes \\
\hline \multirow[t]{6}{*}{3.} & \multirow[t]{6}{*}{ Outside the school canteen $(\mathrm{C})$} & Green bean drinks \\
\hline & & Sticky rice drinks \\
\hline & & Orange drinks \\
\hline & & Fruit juice \\
\hline & & Ice cubes \\
\hline & & Instant drinks \\
\hline \multirow[t]{2}{*}{4.} & \multirow[t]{2}{*}{ Outside the school canteen (D) } & Soybean drinks \\
\hline & & Ice cubes \\
\hline 5. & Outside the school canteen (E) & Es kertas \\
\hline
\end{tabular}

consisting of Indole, MR, VP, citrate, semi-solid, urea, TSIA and then incubated 24 hours.

As the samples were collected, the vendors were interviewed to find out more about the ingredients, location, and hygiene condition of the vendors.

\section{Results}

A total of 20 samples collected from inside and outside the school canteen. The samples were all beverages that were sold there (Table 1).

From 20 samples, 11 types of bacteria were identified. None of the samples with negative values of bacterial contamination. The absence of Salmonella sp. presumably because there was no Salmonella sp. in the ingredients, the bacteria were killed by the heat during food processing, or no Salmonella sp. on all equipment and workers (Table 2).

The Escherichia coli bacterial contamination in canteen (A) was identified in 2 out of 5 samples and 4 out of 6 samples in canteen (B), both of the canteens used refill mineral water as ingredient and tap water to wash the equipment. Klebsiella spp. found in grass jelly drinks from canteen (B), orange drinks form canteen (C) and soybean drinks from canteen (D). Most of the beverages from outside the school canteen had bacterial contamination. Zoonotic bacterial growth was found in the sample, namely Edwardsiella tarda which is an opportunistic pathogen found in areas with high consumption of raw fish (Table 3). 
Table 2. Bacteriological Identification

\begin{tabular}{cll}
\hline No & \multicolumn{1}{c}{ Types of Beverages } & \multicolumn{1}{c}{ Bacteriological Identification } \\
\hline 1. & Tea (A) & Enterobacter agglomerans \\
\hline 2. & Orange drinks (A) & Escherichia coli \\
\hline 3. & Chocolate milk "Milo" (A) & Escherichia fergusoni \\
\hline 4. & Ice cream "cap jempol” (A) & Escherichia coli \\
\hline 5. & Ice cubes (A) & Yersinia intermedia \\
\hline 6. & Tea (B) & Escherichia coli \\
\hline 7. & Chocolate milk "Milo" (B) & Escherichia coli \\
\hline 8 & Milk (B) & Enterobacter gergoviae \\
\hline 9. & Syrup drinks (B) & Escherichia coli \\
\hline 10. & Grass jelly drinks (B) & Klebsiella pneumoni \& Escherichia coli \\
\hline 11. & Ice cubes (B) & Yersinia intermedia \\
\hline 12. & Green bean drinks (C) & Enterobacter agglomerans \\
\hline 13. & Sticky rice drinks (C) & Escherichia vulneris \\
\hline 14. & Orange drinks (C) & Klebsiella pneumoni \\
\hline 15. & Fruit juices (C) & Escherichia coli \\
\hline 16. & Ice cubes (C) & Escherichia coli \& Shigella spp. \\
\hline 17. & Instant drinks (C) & Klebsiella oxytoca \& Yersinia intermedia \\
\hline 18. & Ice cubes (D) & Morganella morgani \\
\hline 19. & Soybean drinks (D) & Klebsiella oxytoca \\
\hline 20. & Es Kertas (E) & Escherichia coli \& Edwardsiella tarda \\
\hline
\end{tabular}

Table 3. The Distribution of the Bacteria

\begin{tabular}{ll}
\hline Bacteria & Percentage \\
\hline Escherichia coli & $37,5 \%(9 / 24)$ \\
\hline Yersinia intermedia & $12,5 \%(3 / 24)$ \\
\hline Enterobacter agglomerans & $8,3 \%(2 / 24)$ \\
\hline Klebsiella oxytoca & $8,3 \%(2 / 24)$ \\
\hline Klebsiella pneumoni & $8,3 \%(2 / 24)$ \\
\hline Escherichia fergusoni & $4,1 \%(1 / 24)$ \\
\hline Enterobacter gergoviae & $4,1 \%(1 / 24)$ \\
\hline Escherichia vulneris & $4,1 \%(1 / 24)$ \\
\hline Edwardsiella tarda & $4,1 \%(1 / 24)$ \\
\hline Morganella morgani & $4,1 \%(1 / 24)$ \\
\hline Shigella spp. & $4,1 \%(1 / 24)$ \\
\hline
\end{tabular}

The highest percentage of bacterial contamination was Escherecia coli and Yersinia intermedia, both are groups of gram-negative bacteria. This result showed poor quality of beverages, and potential in foodborne transmission (Table 3$)^{8}$

\section{Discussion}

There was no Salmonella sp. found in all samples in this study. A study showed that Salmonella sp. cannot compete with other bacteria, its growth will be severely inhibited. ${ }^{9}$ In addition, the samples were collected in the morning when the equipment was still clean, few flies and dust attached to equipment and beverages. This result was similar with a study showed 35 Panganan Jajanan Anak Sekolah (PJAS) samples without Salmonella contamination. ${ }^{10}$
In beverages, Escherichia coli contamination can be an indicator that the water used is contaminated by feces. Yersinia intermedia was found in ice cubes from canteen (A) and (B), which had similarities using ice cubes in packs. These bacteria can be found in the environment, such as fresh water and wastewater, but these bacteria do not cause gastrointestinal diseases. ${ }^{11} \mathrm{~A}$ study showed that the main source of contamination are water and ice that are not cooked properly. ${ }^{12}$ Klebsiella spp. contamination in beverages was caused by the contaminated water and aerosol bacteria which was spread by sneezing or coughing. ${ }^{13}$ Edwardsiella tarda contamination was found only in "es kertas" sold outside the school canteen, this is caused by the contaminated water and unwashed hands.

The bacterial contamination mentioned above can be caused by several factors, including ingredients and 
equipment, hand use without gloves or unwashed hands, inappropriate cooking process and serving, and the environment of the school. ${ }^{14,15}$ In addition, the vendors low awareness about personal hygiene can be a source of contamination in beverages.

From the observations, no vendors wore aprons during the cooking process and serving in the school. The results of this study were similar to study showed that $85 \%$ of food vendors do not wear aprons while selling the food and beverages. ${ }^{6}$ An apron is a cloth cover and used as a protector to keep clothes clean. Clean clothes will improve sanitation and hygiene of snacks because there is no dust or dirt attached to clothing that can indirectly contaminate the snacks. The equipment used to sell the beverages can be a source of contamination, such as unsterilized or unwashed equipment and its storage. The use of unwashed hands or without gloves can also be a source of contamination, from the cooking process to serving process, therefore gloves are needed. ${ }^{2}$

\section{Conclusion}

No Salmonella sp bacteria were found in this study. However, the contamination by Enterobacter agglomerans, Enterobacter gergoviae, Escherichia coli, Escherichia fergusoni, Escherichia vulneris, Edwardsiella tarda, Klebsiella oxytoca, Klebsiella pneumoni, Morganella morganii, Shigella spp., and Yersinia intermedia were found in some samples.

\section{Conflict of Interest}

The author stated there is no conflict of interest.

\section{References}

1. RI D. Situasi Diare di Indonesia. In: kesehatan d, (ed.). 2011

2. Naria E. Higiene Sanitasi Makanan dan Minuman Jajanan di Kompleks USU Medan. Jurnal Departemen Kesehatan Lingkungan Universitas Sumatra Utara. 2006: 118-26.

3. Lung E. Acute Diarrheal Disease. In: Friedman S, McQuaid K and Grendell J, (eds.). Current Diagnosis and Treatment in Gastroenterology. New York: Lange Medical Book, 2003, p. 13150.

4. CDC. Diagnosis and Treatment-Salmonella. 2013.

5. Nurlaela E. Food Security and Behavior of Food Handlers in Hospital Nutrition Installation. Makasar: Univeristas Hassanudin, 2011.

6. Susanna D and Budi H. Pemantauan Kualitas Makanan Ketoprak dan Gado-Gado di Lingkungan Kampus UI Depok Melalui Pemeriksaan Bakteriologis. Makara Seri Kesehatan. 2003; 7: 21-9.

7. Ariyani D and Anwar F. Mutu Mikrobiologis Minuman Jajanan di Sekolah Dasar Wilayah Bogor Tengah. Jurnal Gizi dan Pangan. 2006; 1: 44-50.

8. Khan I, Shah MA, Mehmood FQ, Saeed A and Sualeeh M. Determination and Identification of Enterobacteriaceae in Street Vended Foods in Karachi Pakistan. Pakistan Journal of Nutrition. 2015; 14: 225-8.

9. Supardi I, dan Sukamto. Mikrobiologi dalam Pengolahan dan Keamanan Pangan. Bandung: Penerbit Alumni, 1999.

10. Yunita NA. Identifikasi dan Karakterisasi Bahaya Bakteri Patogen Pada Pangan Jajanan Anak Sekolah di Bogor. Bogor: IPB, 2015.

11. CDC. Salmonellosis. 2009.

12. R.L P. Kualitas Jajanan Siswa Sekolah Dasar. Jurnal Al-Azhar Indoesia Seri Sains dan Teknologi. 2013; 2: 52-6.
13. A D, G.S N, S B and S B. Microbiology Quality of Street Vended Indian Chaats Sold in Bangalore. Biol Sci. 2010; 10: 255-60.

14. Agustina F. Higiene dan Sanitasi pada Pedagang Makanan Jajanan Tradisional di Lingkungan Sekolah Dasar di Keurahan Demang Lebar Daun Palembang Tahun 2009. Palembang: Universitas Sriwijaya, 2009.

15. Barro N, Bello AR, Savadogo A, Ouattara CAA, A.J.Ilboudo and Traore AS. Hygienic Status Assessment of Dishwater, Utensils, Hands and Pieces of Money in Street Foods Vending Sites in Ouagadouguo: Burkina Faso. Afr J Biotechnol. 2006; 5: 1107-12. 